\title{
Individual level culture influence on online consumer iTrust aspects towards purchase intention across cultures: A S-O-R model
}

\author{
Osama Sohaib* and Kyeong Kang \\ Faculty of Engineering and Information Technology, \\ University of Technology, Sydney, \\ Ultimo, NSW 2007, Australia \\ Email: osama.sohaib@uts.edu.au \\ Email: kyeong.kang@uts.edu.au \\ ${ }^{*}$ Corresponding author
}

\begin{abstract}
Building trust and understanding its relationship with online purchasing decisions is important to business-to-consumer (B2C) e-commerce firms seeking to extend their consumers reach globally. Based on the StimulusOrganism-Response (S-O-R) model, this paper examines the moderating role of culture on the relationship between B2C web design (web accessibility, visual appearance and social networking services (SNS)) and interpersonal trust (iTrust), cognitive and affect-based trust that trigger online purchasing intentions. Motivation of this study includes, testing and comparing individual consumer level cultural (individualism and uncertainty avoidance) values as moderators in our research model across two different societies (Australia and Pakistan). The data of the survey were analysed using structural equation modelling-partial least square (SEM-PLS) approach. The results highlight the need to consider cultural differences when identifying the mix of web design strategies to employ in $\mathrm{B} 2 \mathrm{C}$ e-commerce websites, not only at the country level but also in one culturally diverse country such as Australia.
\end{abstract}

Keywords: B2C; business-to-consumer; e-commerce; e-business; culture; cognitive-based trust; affect-based trust; purchase intention; iTrust; interpersonal trust; reflective and formative construct; Australia; Pakistan.

Reference to this paper should be made as follows: Sohaib, O. and Kang, K. (2015) 'Individual level culture influence on online consumer iTrust aspects towards purchase intention across cultures: A S-O-R model', Int. J. Electronic Business, Vol. 12, No. 2, pp.142-161.

Biographical notes: Osama Sohaib is perusing $\mathrm{PhD}$ (2012-2015) in Information Systems and a causal academic at Faculty of Engineering and Information Technology, University of Technology, Sydney. His research interest includes trust, usability and cultural issues in e-commerce, innovation, knowledge management and design thinking.

Kyeong Kang, PhD is a Lecturer in Faculty of Engineering and Information Technology, University of Technology, Sydney. Her current research interest includes, impact of the cognition, collaboration and cultural issues in e-services. Her research publications include papers in prestigious journals and conferences. 


\section{Introduction}

A website is the main way an e-business firm communicates with its online consumers. In order to form a consumer trust in e-commerce context, e-vendors try to provide positive online purchasing experiences for potential consumers. For-example, a website appearance encourages or discourages a consumer's online purchasing intention (Cyr, 2013). A first visitor to an online store largely form their first impression from the website user interface, and hence cognitive-based trust can be affected by the website interface (Lim et al., 2006). In particular, the development of business-to-consumer (B2C) websites those are visually pleasing, accessible content information and easy to navigate influence consumer trust with cognitive and affective responses (Éthier et al., 2008; Cyr, 2013). Previous research dealing with factors of online trust in e-commerce (Gefen et al., 2003; Kim et al., 2008; Ou and Sia, 2009; Palvia, 2009; Sun, 2010) has identified adequately of trust factors such as, third trusted party seal, web assurance, disposition to trust, familiarity, security, privacy, social-cue design and attitude by assuming that these trust factors are built uniformly across different cultures. In addition, researchers have found that online trust formed differently in different cultures in e-commerce context (Sia et al., 2009; Cyr, 2013). However, country has been used as a proxy for culture at a group level by several past researchers in cross-cultural studies such as Lee et al. (2007) and Cyr (2008). B2C refers to the e-commerce model in which business sells directly to individual shoppers (Bidgoli, 2002). Online purchasing is not only individual oriented, but also culture can manifest itself through the individuals. McCoy et al. (2005) argued that it is inappropriate to use Hofstede's (1980) country scores on cultural dimensions because members of a society need not have the same cultural values. Considering nations as a culture raised problems because within country heterogeneity may be greater than between culture heterogeneity (Hofstede, 1980). Therefore the level of analysis at the individual level is most appropriate in B2C context.

In addition, the number of online trust research studies overall remains limited because of the trust influencing factors are mainly based on the western background but not valid in other cultural scenarios (Binhui et al., 2011). The adoption rate of online purchasing is low in Asian countries as compared to the Western world (Lee et al., 2010). E-commerce has the ability to attract global consumers to improve productivity. However, there have been some uncertainties in the significance of e-business in developing countries (Lawrence and Usman, 2010). Hence, gap in the literature still exists. Therefore, the contribution of this study includes examining Pakistani B2C e-commerce, which is relatively an unexplored area of online trust in the e-commerce context. We also wished to examine the differences of our proposed model between developing country (Pakistan) and developed country (Australia), where the use of online shopping is thriving. Pakistan is a developing country of south Asia with an increasing trend of internet users that reached approx. 30 million, while the number of internet users per 100 in Australia was 82 until 2013 and ranked 24 worldwide (WDI, 2011).

This study focuses on two specific process of developing initial trust; cognitive and affect-based trust aspects of B2C website design. In particular, the interpersonal trust (iTrust) in computer-mediated communication is a new research topic for e-commerce (Thomas et al., 2012). The literature typically differentiates two broad foundations of 
iTrust as cognitive and affect-based trust; cognitive-based trust is built on the available knowledge and good reasons for decision making, whereas affect-based trust is built on the emotional ties between partners (McKnight et al., 1998).

We adopted the Stimulus-Organism-Response (S-O-R) approach to understand the formation of cognitive and affective influences of online consumers towards purchasing intention in a $\mathrm{B} 2 \mathrm{C}$ context. The $\mathrm{S}-\mathrm{O}-\mathrm{R}$ model suggests that environmental cues (Stimuli) effect an individual's cognitive and affective reaction (Organism) that further influences individual's behaviour (Response) (Mehrabian and Russell, 1974). Using S-O-R framework, the same stimuli can create different responses with differing cultural values. Therefore, this study focuses on the moderating role of individualism (IDV) culture value on visual appearance (colour and images), social networking services (SNS) and uncertainty avoidance (UA) culture value on web accessibility and on iTrust (cognitive and affect-based trust) (Organism) towards purchase intention (Response). Following the above-mentioned, our research question is: Does the national culture value of uncertainty avoidance (UA) and Individualism (IDV) influences online iTrust (iTrust) aspects at the individual consumer level towards purchasing intention in B2C e-commerce across cultures?

\section{Background and related studies}

\subsection{Culture differences in e-commerce}

Hofstede et al. (2010) defines culture as "the collective programming of the mind which distinguishes the members of one group or category of people from another". In line with cultural differences in B2C e-commerce, Hofstede's (1980) cultural aspects have been comprehensively used and validated in prior e-commerce research studies (Kim, 2005; Sinkovics et al., 2007; Teo and Liu, 2007; An and Kim, 2008; Yoon, 2009; Ganguly et al., 2010). Hofstede's cultural dimensions show a clear difference between Australia and Pakistan. For-example, individualism-collectivism (IDV) dimension with an index score (Australia: 90; Pakistan: 14; difference: 76), and uncertainty avoidance (UA) (Australia: 51; Pakistan: 70; difference: 19). Sohaib and Kang (2014) investigated cultural aspects of Pakistani and Australian B2C websites and the finding showed that there are differences in the representation of functional and hedonic aspects on the $\mathrm{B} 2 \mathrm{C}$ websites both in Australia and Pakistan.

\section{2 iTrust in B2C e-commerce}

iTrust denotes the individual trust made in another party (McKnight and Chervany, 2001). In B2C e-commerce environment, the two parties are the online consumer and the online vendor (Tan and Sutherland, 2004). Two aspects of iTrust are cognitive and affect-based aspects (Johnson and Grayson, 2005). Cognitive-based trust develops from a "pattern of careful rational thinking and thus it reflects the customer's confidence that an e-retailer is honest, accurate, and dependable and keeps promises", whereas affect-based trust also called emotional trust, "develops from one's instincts, intuition, or feelings concerning whether an individual, group or organisation is trustworthy" (Brengman and Karimov, 2012). Previously conducted research have examined cognitive-based trust determinants (such as, perceived security and privacy awareness, system reliability, 
information quality and coherence etc.) and affect-based trust aspects (such as mystery, joy and fear, presence of third party seal, reputation, word-of- mouth, referral, variety etc.) in e-commerce (Johnson and Grayson, 2005; Kim, 2005; Kim et al., 2008; Lee and Kozar, 2010; Eastlick and Lotz, 2011; Li et al., 2011). The findings showed that these factors have significant effects towards online purchasing intention.

\subsection{Web accessibility in B2C e-commerce}

The World Wide Web Consortium (W3C, 2005) defines web accessibility as "people with disabilities can perceive, understand, navigate, and interact with the web". The significance of web accessibility standards in e-commerce has been known around the world (Bernard and Makienko, 2011; Sohaib and Kang, 2012). Sambhanthan and Good (2012) believes that the lack of conformance to accessibility guidelines in e-commerce website reduce the overall accessibility and hence results in poor readability and less navigable page designs. The purpose of web accessibility is to help make the webpages operable for consumers of all ages and with disabilities such as colour blindness. For-example, a colour-blind user making online purchase will not differentiate the red font highlighting the discounted prices. Therefore, e-commerce websites must also follow web accessibility by law (Smallman, 2006; Roggio, 2008). There is a need of quality measurement criteria such as usability and accessibility for e-commerce (Hasan and Abuelrub, 2011). According to the Sohaib and Kang (2013), the presentation of B2C e-commerce web design features are not conveyed through web accessibility guidelines to the global consumer's perception. Wang (2011) finds that the interaction design is a significant aspect to analyse an e-commerce website accessibility. E-commerce website features such as layout, graphics and ease of use can influence consumers clicking frequency and their appearance can encourage or discourage a consumer's purchase intentions (Cyr et al., 2005). According to Nielson (2012), "The first law of e-commerce is that if users cannot find the product, they cannot buy it either".

Web accessibility in e-commerce is one of the critical issues for e-business firms, not only to attract consumers but so they can meet their business targets. The web accessibility concept adopted here considers the ease-of use and usefulness aspects together with various design features that contribute to the overall website usability (such as, navigability, structure and attractiveness).

\subsection{Visual appearance (colour and images) in B2C e-commerce}

Web design aesthetic elements, such as colour and images are important determinants of the consumer's trust and intention to buy a product (Lorenzo-Romero et al., 2013). Website colour appeal is an important factor for website trust and there are differences in consumer perception across cultures (Cyr et al., 2010). Website colours have the potential to affect users' behaviours and cognitive process (Bonnardel et al., 2011). Ganguly et al. (2009) argued and empirically recognised that the visual design aspects of e-commerce website such as graphics, colours, and photographs positively affects trust with the online store. Pelet (2011) also found that colour is an important web design factor affecting the consumer trust. Concerning the image feature in e-commerce, some e-vendors focuses on more advanced image interactivity technology, such as three-dimensional (3D) virtual models, 360 degree rotation view which allows the manipulation of product images to imitate actual experiences with the product (Kim and Forsythe, 2007, 2009; 
Hyun-Hwa et al., 2010). According to Corritore et al. (2003) images have an impact on trustworthiness. Moreover, Images meaning in one culture may not reflect the same meaning in another culture (Chakraborty, 2009).

\subsection{Social networking services in B2C e-commerce}

Social networking is defined as a set of actors (people/organisations) and the set of connections among the actors representing some relationship (friendship/affiliation/ information exchange) (Grabner-Kräuter, 2009). The web now enables collaboration through SNS among consumers, such as online discussion forums, blogs, social networks sites etc. Such applications are also significantly changing the relationship between consumers and e-retailers (Lee et al., 2011). For-example, by creating its official page on some social networks sites like Facebook, Twitter; the company can provide an opportunity to get closer to their offers through interactions between consumers (Thabet and Zghal, 2013). In Australia, according to 2012 digital media research, " $29 \%$ of all online shoppers in Australia currently follow an online shopping site on Facebook, and $21 \%$ has received a message or recommendation from a friend in the prior year on Facebook, whilst $14 \%$ has made a recommendation". More than $72 \%$ of internet users are engaged in a social media websites, so there is a need to create a social media presence for e-commerce website (Najjar, 2011). According to Brengman and Karimov (2012) the "presence of social network application in a web interface may allow users to experience others as being psychologically present in the virtual environment. Gefen and Straub (2004) found the significant influences of social presence on consumer trust such as ability, integrity, predictability and benevolence in $\mathrm{B} 2 \mathrm{C}$ e-commerce. However, the SNS still needs to be investigated in e-commerce context across cultures.

\section{Theoretical development and research model}

We used the S-O- $\mathrm{R}$ model to identify both cognitive and affect-based trust aspects in order to determine the iTrust towards purchasing intention. S-O-R paradigm was first proposed by Mehrabian and Russell (1974) in the context of environmental psychology. The paradigm suggests that stimuli from environments influence an individual's cognitive and affective reactions, which in turn lead to some response and behaviour. This paradigm was later extended and has been extensively applied to shopping outcomes of online stores. In the context of online shopping, the stimulus (S) is defined as "the total sum of all the cues that are visible and audible to the online shopper". The internal states (Organism) affect consumer responses, such as purchase intention (Response). Cognitive and affective signs are present in a B2C website (Karimov et al., 2011). A cognitiveaffective model of communication for designing information technology developed by Te'eni (2001), which includes communication medium and the message form have an impact on how the communication is received from the website itself (Cyr et al., 2010). With references to this research, the $\mathrm{B} 2 \mathrm{C}$ e-commerce website is the medium, and the message form is characterised by consumer's cognitive and affective responses with potential to influence iTrust towards purchasing intention.

The cognition-based trust is associated with consumers' observations and perceptions regarding the features and characteristics of an e-commerce website. The affect-based trust is associated to indirect interactions with the other sources such as inputs 
from others (e.g., trusted third-party seal, referral, comments, recommendation, etc.) (Kim, 2005). Therefore, cognitive-based trust is a consumer confidence to rely on B2C design (such as, web accessibility/colour and images) along with SNS (Chelule, 2010), while affect-based trust is the satisfying experience (feelings) demonstrated by the website itself (Éthier et al., 2008). Moreover, to establish an iTrust, consumers in dissimilar cultures might have different expectations of what makes an online store trustworthy (Kim, 2005; Sia et al., 2009; Ganguly et al., 2010; Kim and Park, 2013).

Drawing from previous models and theories of trust building processes in e-commerce, a model is proposed to describe how a consumer iTrust using an e-commerce websites and intention to purchase online are formed (Figure 1). The goal is not to provide a comprehensive view of all aspects influencing the formation of trust and intention to purchase. Rather, the emphasis is on revealing the role of immediate cognitive and affective responses in the trust building process towards online purchasing intention. Moreover, this research applied individualism (IDV) and uncertainty avoidance (UA) culture dimensions at the individual consumer level, because these are considered highly relevant to trust in cross-culture business relationships (McCoy et al., 2005; Cyr, 2013).

Figure 1 Research model

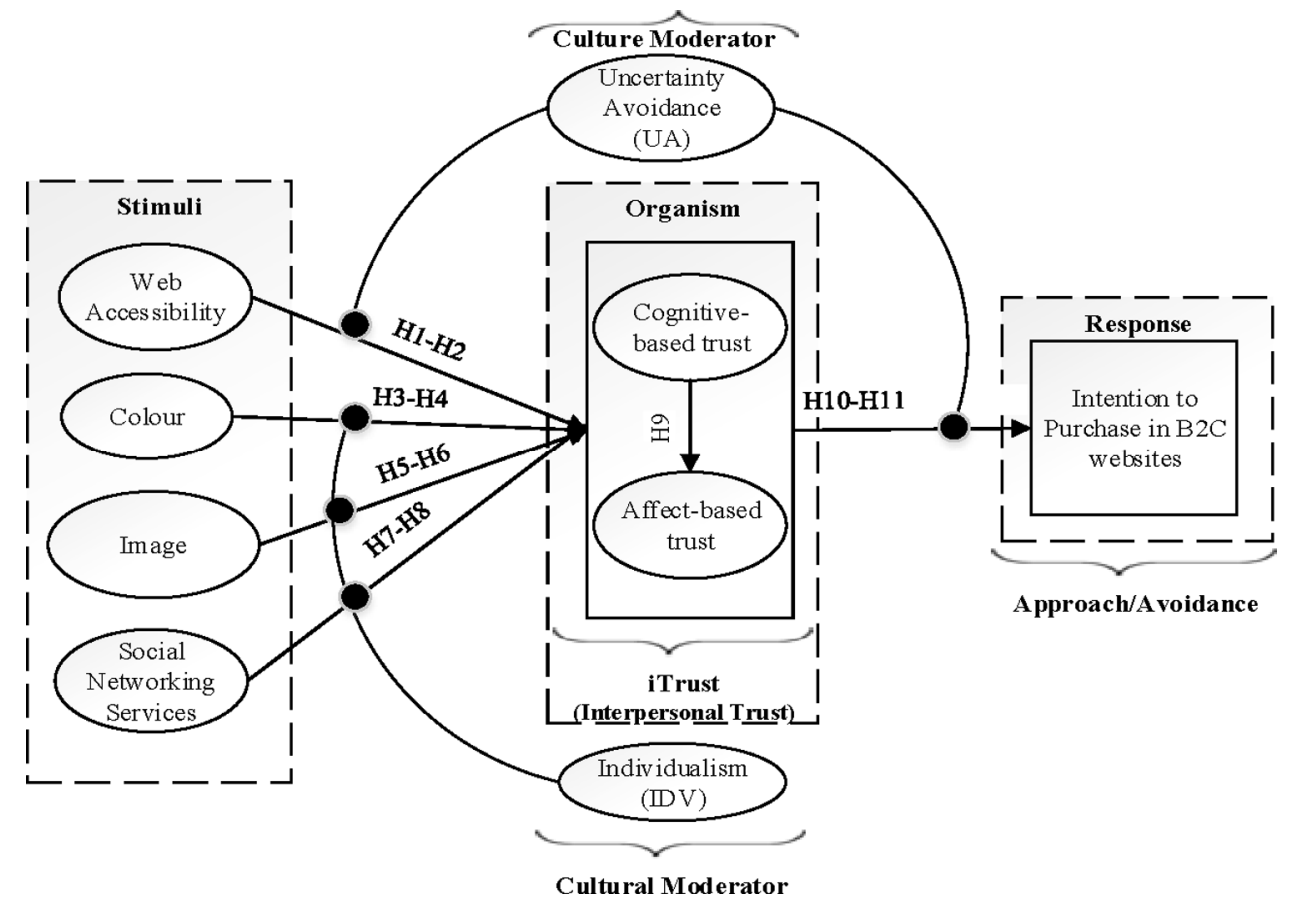

\subsection{Hypothesis development}

Cyr et al. (2004) believes that e-commerce website has to be design with ease of access on a complete understanding of a consumer group's culture. The website navigation, page layout consistency and easy access to navigational features are universally desirable (Cyr, 2013). Singh et al. (2005) discussed that customers from high UA societies 
needs better web accessibility so that they do not get lost website. Cyr (2008) found that consumers who are high on UA give more preference to web design, such as navigational design for generating trust. Yoon (2009), discussed the moderating role of UA on perceived usefulness and found that consumers with a high degree of UA feels lower trust to engage in online shopping because they usually perceive e-commerce as having uncertain effects. Consumers who are low on UA like getting into more logical flow of information, which allows them to complete the transaction on their own. Therefore we hypothesise.

H1: The relationship between web accessibility and cognitive-based trust is moderated by the cultural value of UA such that the relationship is stronger for individuals in Pakistan than in Australia.

H2: The relationship between web accessibility and affect-based trust is moderated by the cultural value of UA such that the relationship is stronger for individuals in Australia than in Pakistan.

The use of images and colour provide appeals to the consumer emotions and a positive impression of the overall graphical look of a website across cultures (Cyr, 2013). According to Ford and Kotz (2005) colour and images should be used in interface design to prevent end-user from getting lost in collectivistic cultures, while it should be used to provide additional information in Individualistic cultures. Visual appearance such as colour and images resulted in high trust in collectivistic cultures but not in individualistic cultures (Cyr, 2008). Besides, the authors in Ganguly et al. (2010) discussed that visual appearance are preferred more by collectivist consumers than individualistic. Therefore, we hypothesise.

H3: The relationship between colour and cognitive-based trust is moderated by the cultural value of IDV such that the relationship is stronger for individuals in Pakistan than in Australia.

H4: The relationship between colour and affect-based trust is moderated by the cultural value of IDV such that the relationship is stronger for individuals in Pakistan than in Australia.

H5: The relationship between images and cognitive -based trust is moderated by the cultural value of IDV such that the relationship is stronger for individuals in Pakistan than in Australia.

H6: The relationship between images and affect-based trust is moderated by the cultural value of IDV such that the relationship is stronger for individuals in Pakistan than in Australia.

With the global popularity of SNS, B2C e-commerce websites are integrating social networking elements to reach their target customers and achieve their business goals effectively across cultures (Sun, 2011). Social influence can build consumer trust in online shopping more effective in the collectivistic culture than in the individualistic culture (Lee et al., 2011). For-example, people in collectivist's culture such as Pakistan are more likely to perceived reputation from friends and family recommendations, whereas individualist cultures such as Australians are more likely to take independent decisions. 
H7: The relationship between social networking services and cognitive-based trust is moderated by the cultural value of IDV such that the relationship is stronger for individuals in Pakistan than in Australia.

H8: The relationship between social networking services and affect-based trust is moderated by the cultural value of IDV such that the relationship is stronger for individuals in Pakistan than in Australia.

Cognitive-based trust should exist before the affect-based trust develops (Johnson and Grayson, 2005). Cognitive and affective skills affect each other and consumers do not use them independently (Hansen, 2005). Adoption rates of online shopping are higher for individualist than for collectivist cultures (Lim et al., 2004). Yoon (2009) also noted that individualistic are usually more willing to rely on online shopping and trust them than a collectivist. Whereas, consumer's in a high UA culture have less effect on trust towards intention to purchase. Therefore, we propose.

H9: Cognitive-based trust positively influences affect-based trust in Pakistani ecommerce context than in Australia.

H10: The relationship between cognitive-based trust and purchase intention is moderated by the cultural value of UA such that the relationship is stronger for individuals in Australia than in Pakistan.

H11: The relationship between affect-based trust and purchase intention is moderated by the cultural value of UA such that the relationship is stronger for individuals in Australia than in Pakistan.

\section{Methodology}

For the validation and testing the hypotheses in a cross-cultural setting, set of data were collected from students at universities in Australia and Pakistan. Universities students are composed of the majority of online users and the internet usage is comparatively higher than other aged group. This study used an online survey methodology where participants in each research site were asked to choose a localised online vendor. A well localised retailer website are considered to be appropriate to the culture and most workable option for research (Cyr, 2013). The participants from Pakistan were asked to visit (homeshopping.pk) and participants from Australia to visit (http://www.oo.com.au/), and assume that they are interested in buying a product offered by that company by ignoring the price factor. The participants were instructed to search for any product and gather certain details to become more familiar with the chosen website (Chen and Barnes 2007) and to go through the entire online buying process up to but excluding the clicking of the buy button to purchase the product. After the interaction with the chosen website, respondents were required to fill-out a closed-ended questionnaire on seven - point Likert scale. This includes options such as 7. Strongly Disagree, 6. Disagree, 5. Somewhat Disagree, 4. Neither Agree not Disagree, 3. Somewhat Agree, 2. Agree and 1. Strongly agree. Medium of instruction in Pakistani educational institutions is English. Thus, there was no need to translate the questionnaires into local language. 
Previously validated survey instruments were revised and used in order to ensure the measures are adequate and representative. Appendix A shows all items used in this study. In this research the culture effects on trust aspects and online purchasing intention is observed at individual consumer level using two sets of data collected from two different national cultures: Australia (Individualistic and low Uncertainty Avoidance) and Pakistan (Collectivistic and high Uncertainty Avoidance). The Hofstede national culture dimensions are based on the assumption that there are more cultural differences between countries. We believe that by using the data from two different culture countries (Australia and Pakistan) it would be possible to determine whether cultural values operate at the individual level. However, Hofstede warned that his cultural instrument couldn't be used to test individual level relationship, because the items address issues from business people's point of view, not from individual's point of view. Fortunately, (Dorfman and Howell, 1988) provided an encouraging cultural instrument at the individual level based on Hofsetde cultural dimensions. Therefore, the Individualism and Uncertainty Avoidance scales were taken. The researchers (McCoy et al., 2005; Srite and Karahanna, 2006; Yoon, 2009) found the scales acceptable in information systems research and thereby adding to the items validity.

\section{Data analysis}

Data collection lasted from November 2013 to February 2014. A total of 280 responses from Pakistan and 263 responses from Australia were collected. After removing incomplete responses, a total of 270 Pakistan and 255 Australia samples were used to test the proposed model. The two groups were also comparable in that they composed of students enrolled in information systems course. In Pakistan sample, $65 \%$ respondent were males and $35 \%$ was females, $70 \%$ respondents had internet experience of seven years or above, $45 \%$ respondents have online purchasing experience between 1-3 years. On the other hand, In Australia sample, 55\% respondent were males and 45\% was females, $87 \%$ respondents had internet experience seven years or above, $58 \%$ respondents have online purchasing experience between 1-3 years.

Variance-based structural equation modelling (SEM) statistical technique, such as partial least squares (PLS) path modelling using SmartPLS version 3 (Ringle et al., 2014) was used to test the research model. PLS is considered appropriate as it allows researchers to simultaneously assess measurement model parameters and structural path coefficients. Furthermore, it allows both formative and reflective constructs to be tested together (Chin et al., 2003). In our research model, web accessibility, colour and image, cognitive-based trust, affect-based trust and purchase intention were modelled as reflective indicators because they were viewed as effects of latent variables (Kim, 2005; Hwang and Lee, 2012). Reflective indicators are interchangeable, For example, different indicators reflect web accessibility, such as easy to learn, easy to use and clear and understandable, to which it is highly correlated. So, an increase in web accessibility is reflected by increases in all indicators. Whereas SNS is formative in nature because it is a multidimensional construct, which cover various referent groups such as social networks sites, friends and family, online help, reviews and rankings. Formative construct is not interchangeable, which means change in one indicator does not necessarily denote change in other indicator. For-example, an increase in influence from family would influence individual to buy even if there were no influence from other 
sources. In addition, the moderating effects of culture (UA and IDV) on constructs were performed using the product indicator approach. The product indicator approach by Chin (2003) refers to the products of each indicator of the independent latent construct with each indicator of the moderator construct.

\subsection{Reliability and validity assessment}

The measurement models in PLS were evaluated by examining internal consistency, convergent validity and discriminant validity. Convergent and discriminant validity were evaluated by applying two criteria:

- the square root of the average variance extracted (AVE) by a construct from its indicators was at least 0.70 and was greater than that construct's correlation with other constructs

- items loadings were at least 0.70 and are more strongly on their assigned construct rather than on the other construct.

For the Australian and Pakistani model, Table 1 shows the Cronbach's reliability, composite reliability and the AVE of all constructs values exceeds the recommended value of 0.70. A SNS is a formative construct that cannot be analysed in this procedure. For formative indicator (SNS), the validity of construct using outer weights was significant ( $\mathrm{p}$ value $<0.05$ ). In addition to this, to determine the reliability for formative indicators, the variance inflation factor (VIF) value was less than 5 , which means there is no multicollinearity.

\section{Structural model testing}

The structural models and hypotheses were tested, by examining the significance of the path coefficients and the $\left(\mathrm{R}^{2}\right)$ variance for the dependent constructs. The significance of the paths was determined using the t-statistical test calculated with the bootstrapping technique. A 5\% significance level was employed. Further, to compare between group differences (Australia and Pakistan), multi-group PLS analysis method (see Appendix B) was used, which is considered appropriate for this study (Sia et al., 2009). We examined the coefficients of the causal relationships between constructs in our model in order to validate or disprove the hypotheses. The coefficients and their t-value on the structural model, and the coefficients of determination $\left(\mathrm{R}^{2}\right)$ for dependent construct are shown in Table 2 and Figures 2 and 3. Comparing differences in coefficients of the corresponding structural paths of the two research models, as shown in Figure 2 and 3, Variance in consumer's cognitive-based trust $\left(\mathrm{R}^{2}=0.194\right)$ and affect-based trust $\left(\mathrm{R}^{2}=0.614\right)$ in Australian sample is higher than Pakistan sample $\left(R^{2}=0.153\right)$ and $\left(R^{2}=0.134\right)$ respectively. On the other hand, variance in consumer's purchase intention for Australia sample $\left(R^{2}=0.507\right)$ is significant than Pakistan sample $\left(R^{2}=0.259\right)$. Australia sample model indicates $50 \%$ variance in consumer's purchase intention while Pakistani sample explains $25 \%$. 
Table 1 Reliability, correlation, and discriminant validity of constructs (Australia sample)

\begin{tabular}{|c|c|c|c|c|c|c|c|c|c|c|c|c|}
\hline & $A V E$ & $C R$ & C-Alpha & ATrust & CTrust & $C O L$ & $I D V$ & $I M G$ & PINT & SNS & $U A$ & $W A$ \\
\hline \multicolumn{13}{|c|}{ Australia sample } \\
\hline ATrust & 0.825 & 0.934 & 0.893 & 0.908 & & & & & & & & \\
\hline CTrust & 0.790 & 0.896 & 0.833 & 0.161 & 0.889 & & & & & & & \\
\hline $\mathrm{COL}$ & 0.743 & 0.896 & 0.838 & 0.184 & -0.076 & 0.862 & & & & & & \\
\hline IDV & 0.719 & 0.830 & 0.725 & -0.100 & -0.105 & 0.105 & 0.848 & & & & & \\
\hline IMG & 0.776 & 0.862 & 0.769 & 0.176 & -0.064 & -0.104 & 0.023 & 0.881 & & & & \\
\hline PINT & 0.877 & 0.955 & 0.930 & 0.684 & 0.070 & 0.063 & -0.13 & 0.033 & 0.936 & & & \\
\hline SNS & NA & NA & NA & 0.141 & 0.047 & 0.078 & -0.08 & -0.11 & 0.035 & 1 & & \\
\hline UA & 0.732 & 0.835 & 0.763 & 0.151 & 0.057 & 0.130 & -0.12 & -0.02 & 0.140 & 0.022 & 0.855 & \\
\hline WA & 0.921 & 0.986 & 0.983 & 0.707 & 0.017 & 0.109 & 0.007 & 0.075 & 0.647 & 0.209 & 0.061 & 0.959 \\
\hline \multicolumn{13}{|c|}{ Pakistan sample } \\
\hline ATrust & 0.804 & 0.924 & 0.881 & 0.897 & & & & & & & & \\
\hline CTrust & 0.770 & 0.930 & 0.899 & -0.008 & 0.877 & & & & & & & \\
\hline $\mathrm{COL}$ & 0.705 & 0.877 & 0.792 & -0.208 & 0.017 & 0.839 & & & & & & \\
\hline IDV & 0.731 & 0.889 & 0.814 & -0.002 & 0.133 & 0.063 & 0.855 & & & & & \\
\hline IMG & 0.804 & 0.925 & 0.879 & 0.011 & -0.128 & 0.089 & 0.021 & 0.897 & & & & \\
\hline PINT & 0.768 & 0.908 & 0.847 & -0.153 & 0.147 & 0.067 & 0.025 & 0.113 & 0.876 & & & \\
\hline SNS & NA & NA & NA & -0.138 & 0.199 & 0.273 & -0.00 & -0.05 & 0.302 & 1 & & \\
\hline UA & 0.881 & 0.957 & 0.935 & -0.111 & -0.046 & -0.061 & -0.04 & 0.380 & 0.181 & -0.06 & 0.939 & \\
\hline WA & 0.725 & 0.940 & 0.930 & -0.079 & 0.116 & 0.208 & -0.09 & -0.05 & 0.093 & 0.177 & -0.20 & 0.851 \\
\hline
\end{tabular}

1. AVE: Average Variance Extracted, CR: Composite Reliability, C Alpha: Cronbach's Alpha 2. ATrust: Affect-Based Trust, CTrust: Cognitive-Based Trust, COL: Colour, IMG: Image, IDV: Individualism, PINT: Purchase Intention, SNS: Social Networking Services, UA: Uncertainty Avoidance, WA: Web Accessibility 3. Diagonal elements are the square root of AVE.

Table 2 Hypothesis testing results

\begin{tabular}{|c|c|c|c|c|c|c|c|c|}
\hline \multirow[b]{2}{*}{ Hypothesis } & \multirow[b]{2}{*}{ Path } & \multicolumn{2}{|c|}{ Australia } & \multicolumn{2}{|c|}{ Pakistan } & \multirow{2}{*}{$\begin{array}{c}\text { Mean } \\
\text { difference }\end{array}$} & \multirow{2}{*}{$\begin{array}{c}t- \\
\text { tatistics }\end{array}$} & \multirow[b]{2}{*}{ p-value } \\
\hline & & Mean & $S D$ & Mean & $S D$ & & & \\
\hline $\begin{array}{l}\text { H1 } \\
\text { (supported) }\end{array}$ & WA * UA $\rightarrow$ CTrust & -0.198 & 0.097 & 0.068 & 0.090 & -0.266 & 1.955 & $0.045 * * *$ \\
\hline $\begin{array}{l}\mathrm{H} 2 \\
\text { (not supported) }\end{array}$ & WA * UA $\rightarrow$ ATrust & -0.149 & 0.101 & -0.124 & 0.118 & -0.025 & 0.160 & 0.873 \\
\hline $\begin{array}{l}\text { H3 } \\
\text { (supported) }\end{array}$ & $\mathrm{COL} * \mathrm{IDV} \rightarrow \mathrm{C}$ Trust & -0.132 & 0.050 & 0.127 & 0.062 & -0.259 & 3.292 & $0.001 *$ \\
\hline $\begin{array}{l}\mathrm{H} 4 \\
\text { (not supported) }\end{array}$ & $\mathrm{COL} * \mathrm{IDV} \rightarrow$ ATrust & 0.028 & 0.074 & -0.132 & 0.094 & 0.160 & 1.355 & 0.177 \\
\hline
\end{tabular}


Table 2 Hypothesis testing results (continued)

\begin{tabular}{|c|c|c|c|c|c|c|c|c|}
\hline \multirow[b]{2}{*}{ Hypothesis } & \multirow[b]{2}{*}{ Path } & \multicolumn{2}{|c|}{ Australia } & \multicolumn{2}{|c|}{ Pakistan } & \multirow{2}{*}{$\begin{array}{c}\text { Mean } \\
\text { difference }\end{array}$} & \multirow{2}{*}{$\stackrel{t-}{\text { statistics }}$} & \multirow[b]{2}{*}{ p-value } \\
\hline & & Mean & $S D$ & Mean & $S D$ & & & \\
\hline $\begin{array}{l}\text { H5 } \\
\text { (supported) }\end{array}$ & IMG * IDV $\rightarrow$ CTrust & -0.022 & 0.224 & 0.151 & 0.050 & -0.173 & 3.238 & $0.001 *$ \\
\hline $\begin{array}{l}\text { H6 } \\
\text { (supported) }\end{array}$ & IMG $*$ IDV $\rightarrow$ ATrust & -0.178 & 0.048 & 0.163 & 0.101 & -0.341 & 3.186 & $0.002 * *$ \\
\hline $\begin{array}{l}\text { H7 } \\
\text { (supported) }\end{array}$ & SNS $*$ IDV $\rightarrow$ CTrust & 0.006 & 0.014 & 0.083 & 0.016 & -0.077 & 3.723 & $0.000 *$ \\
\hline $\begin{array}{l}\text { H8 } \\
\text { (supported) }\end{array}$ & SNS * IDV $\rightarrow$ ATrust & -0.131 & 0.051 & 0.722 & 0.058 & -0.853 & 11.189 & $0.000^{*}$ \\
\hline $\begin{array}{l}\text { H9 } \\
\text { (supported) }\end{array}$ & CTrust $\rightarrow$ ATrust & -0.075 & 0.078 & 0.122 & 0.072 & -0.197 & 1.977 & $0.049 * * *$ \\
\hline $\begin{array}{l}\text { H10 } \\
\text { (supported) }\end{array}$ & CTrust $*$ UA $\rightarrow$ PINT & -0.169 & 0.086 & 0.160 & 0.107 & -0.329 & 2.434 & $0.016^{* *}$ \\
\hline $\begin{array}{l}\text { H11 } \\
\text { (supported) }\end{array}$ & ATrust $*$ UA $\rightarrow$ PINT & 0.096 & 0.059 & -0.143 & 0.088 & 0.239 & 2.310 & $0.022 * * *$ \\
\hline
\end{tabular}

S.D: Standard Deviation, ATrust: Affect-Based Trust, CTrust: Cognitive-Based Trust, COL: Colour, IMG: Image, IDV: Individualism, PINT: Purchase Intention, SNS: Social Networking Services, UA: Uncertainty Avoidance, WA: Web Accessibility.

*Significant at the 0.001 level; **significant at the 0.01 level; ***significant at the 0.05 level.

Figure 2 Structural model result (Australia sample)

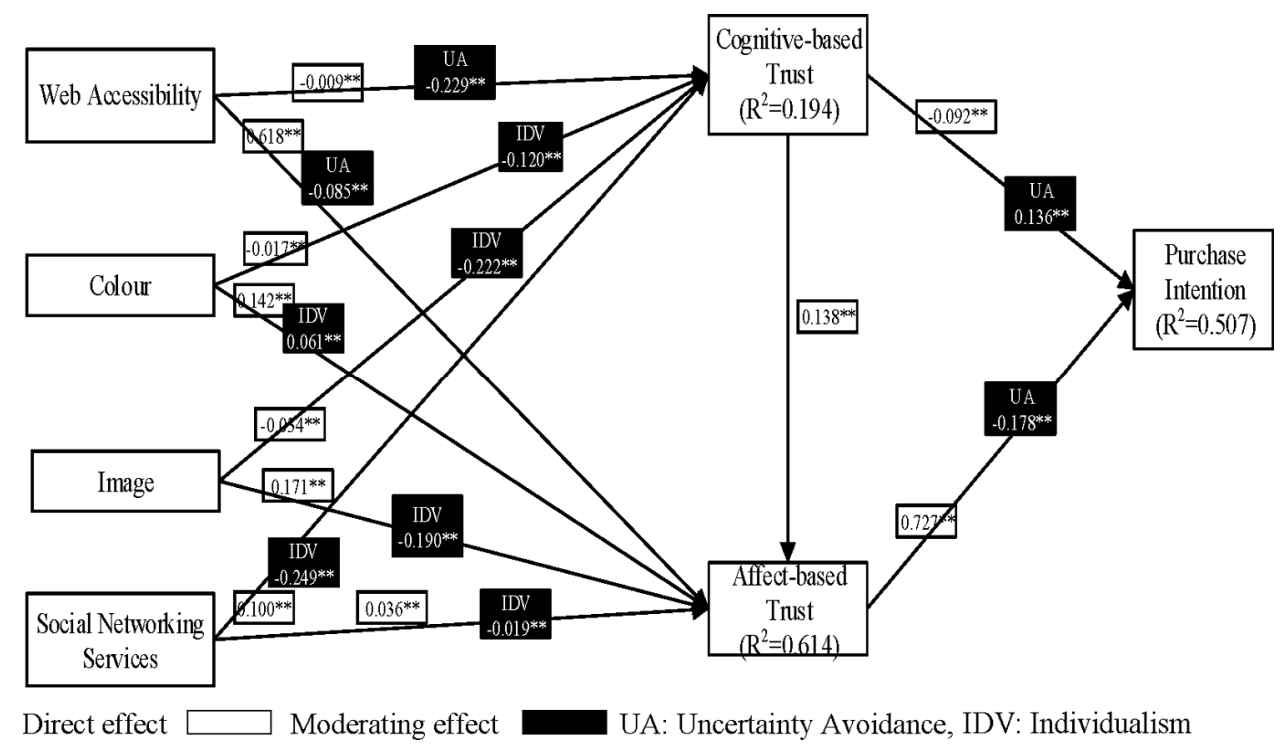


Figure 3 Structural model result (Pakistan sample)

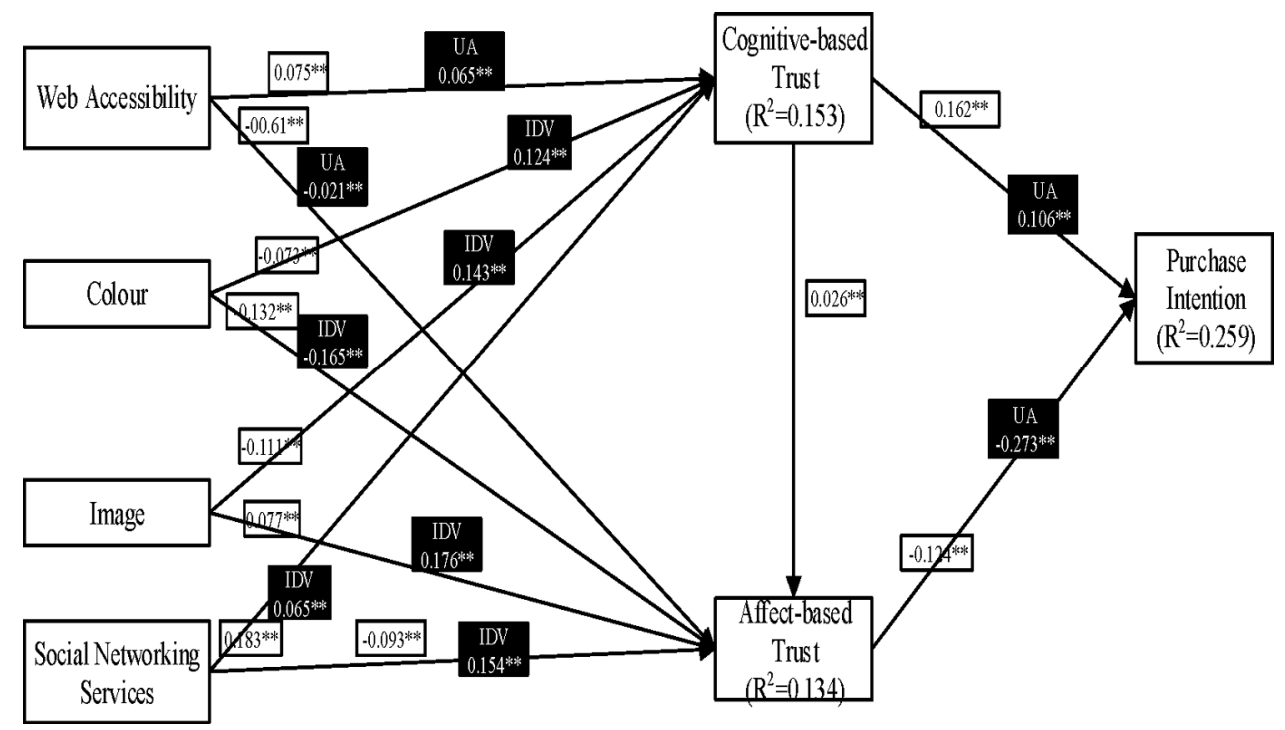

\section{$7 \quad$ Discussion and conclusion}

We empirically tested a model of trust building strategies in B2C e-commerce context across cultures. Data was collected in Australia and Pakistan to explore the effects of culture values (Individualism and Uncertainty Avoidance) at the individual consumer level on iTrust to better understand consumer cognitive and affective responses towards purchasing intentions on $\mathrm{B} 2 \mathrm{C}$ website across cultures.

The findings of this study are: First, we have learnt that the web design factors such as web accessibility, visual appearance (colour and image) and SNS influence cognitive and affect-based trust at the individual level towards purchasing intention across cultures. The uncertainty avoidance (UA) individual effects on the relationship between web accessibility and cognitive-based trust is stronger in Pakistan sample than in an Australia sample. This means that individuals from Pakistan believe that the structural design of a B2C website, including technical aspects such as navigation design, web content information, website availability and accessibility is most important. Visual design preferences vary across countries, in higher uncertainty avoidance societies, website designers should pay particular attention to colours and images (Cyr, 2013). Our results are also consistent with Cyr.

Second, the use intensity of SNS, such as opinions from family/friends, online consumer groups or social media cues (such as social network site, chat rooms, discussions and blogs.) is higher in building the cognitive and affect-based trust towards B2C e-commerce websites in a collectivistic society (Pakistan) than in an individualistic society (Australia).

Third, we have found that differences exist in forming iTrust in online shopping across cultures. In collectivist and high UA culture, consumers are reluctant to engage in online shopping. This is consistent with (Yoon, 2009) study in which the author found that people may decrease online shopping in high UA culture. Finally, contrary to our 
expectation, the effects of colour with moderating role of IDV is insignificant on affectbased trust in Pakistan sample, and web accessibility with the moderating role of UA on affect-based trust is insignificant in Australian sample.

\subsection{Contributions and implications}

It is important to identify web design strategies in B2C e-commerce websites, because the consumer's satisfaction may be completely different across cultures. We highlighted that in-addition to the functional requirements of a $\mathrm{B} 2 \mathrm{C}$ website; the hedonic and social aspects can influence the online consumers to purchase. The results of this study may help online shopping managers who could use the insights analysed in this research to modify their approaches. Developers and website designers could use these understanding to increase desirable outcomes to increase the chances for an online business to succeed in countries with diverse degrees of internet users. For-example, web accessibility can influence the online consumers to purchase. In particular, people with disabilities such as colour-blindness. Practical implications extend to business firms to make changes to their online business strategies to trigger their online sale better, not only across cultures but also in one culturally diverse country such as Australia.

\subsection{Limitations and future work}

Like most survey research, this study also faces some limitations. First, a larger sample size would have been more useful to evaluate the constancy and dependability of the findings. Second, university student's subject was used for data collection in each research site (Australia and Pakistan). The study could be evaluated using different group of internet users. Third, more in-depth studies associated with other practical web design factors for trust building related with other cultural dimensions could be interesting research. Moreover, it will be interesting to see our research model is reasonable acceptable for in-group members living in out-group society.

\section{References}

An, D. and Kim, S. (2008) 'Effects of national culture on the development of consumer trust in online shopping', Seoul Journal of Business, Vol. 14, No. 1, pp.123-151.

Bernard, E.K. and Makienko, I. (2011) 'The effects of information privacy and online shopping experience in e-commerce', Academy of Marketing Studies Journal, Vol. 15, pp.97-112.

Bidgoli, H. (2002) Electronic Commerce: Principles and Practice, Academic Press, California, USA.

Binhui, W., Xuan, G., Huijing, N. and Haoyang, L. (2011) 'A review and prospects of initial trust in e-commerce', 2011 International Conference on Management and Service Science (MASS), IEEE, Wuhun, pp.1-4.

Bonnardel, N., Piolat, A. and Le Bigot, L. (2011) 'The impact of colour on website appeal and users' cognitive processes', Displays, Vol. 32, No. 2, pp.69-80.

Brengman, M. and Karimov, F.P. (2012) 'The effect of web communities on consumers' initial trust in B2C e-commerce websites', Management Research Review, Vol. 35, No. 9, pp.791-817. 
Casaló, L.V., Flavián, C. and Guinalíu, M. (2011) 'The generation of trust in the online service and product distribution. The case of Spanish elcectronic commerce', Journal of Electronic Commerce Research, Vol. 12, No. 3, pp.199-213.

Chakraborty, J. (2009) A Cross-Cultural Usability Study on the Internationalization of User Interfaces Based upon an Empirical Five Factor Model, $\mathrm{PhD}$, University of Maryland.

Chelule, E. (2010) E-Commerce Usability: Do We Need Guidelines for Emerging Economics? IADIS International Interfaces and Human Computer Interaction 2010, Freiburg, Germany, pp.19-26.

Chen, J. and Dibb, S. (2010) 'Consumer trust in the online retail context: exploring the antecedents and consequences', Psychology and Marketing, Vol. 27, No. 4, pp.323-346.

Chen, Y-H. and Barnes, S. (2007) 'Initial trust and online buyer behaviour', Industrial Management \& Data Systems, Vol. 107, No. 1, pp.21-36.

Chin, W.W. (2003) 'A partial least squares latent variable modeling approach for measuring interaction effects: results from a Monte Carlo simulation study and an electronic-mail emotion adoption study', Information Systems Research, Vol. 14, No. 2, pp.189-217.

Chin, W.W. (2004) Multi-Group Analysis with PLS, [Online], Available: http://disc-nt.cba. uh.edu/chin/plsfaq/multigroup.htm

Chin, W.W., Marcolin, B.L. and Newsted, P.R. (2003) 'A partial least squares latent variable modeling approach for measuring interaction effects: results from a Monte Carlo simulation study and an electronic-mail emotion/adoption study', Info. Sys. Research, Vol. 14, No. 2, pp.189-217.

Corritore, C.L., Kracher, B. and Wiedenbeck, S. (2003) 'On-line trust: concepts, evolving themes, a model', Int. J. Hum.-Comput. Stud., Vol. 58, No. 6, pp.737-758.

Cyr, D., Bonanni, C. and Ilsever, J. (2004) 'Design and e-loyalty across cultures in electronic commerce', Paper presented at the Proceedings of the 6th International Conference on Electronic Commerce, Delft, The Netherlands, pp.351-360.

Cyr, D., Bonanni, C., Bowes, J. and Ilsever, J. (2005) 'Beyond trust: web site design preferences across cultures', Journal of Global Information Management (JGIM), Vol. 13, No. 4, pp.1-30.

Cyr, D. (2008) 'Modeling web site design across cultures: relationships to trust, satisfaction, and e-loyalty', J. Manage. Inf. Syst., Vol. 24, No. 4, pp.47-72.

Cyr, D. (2013) 'Website design, trust and culture: An eight country investigation', Electronic Commerce Research and Applications, pp.1-12.

Cyr, D., Head, M. and Larios, H. (2010) 'Colour appeal in website design within and across cultures: a multi-method evaluation', International Journal of Human-Computer Studies, Vol. 68, Nos. 1-2, pp.1-21.

Dorfman, P. and Howell, J.P. (1988) Dimension of National Culture and Effective Leadership Patterns: Hofstede Revisited, Advances in International Comparative Management: A Research Annual, pp. 127-149.

Eastlick, M.A. and Lotz, S. (2011) 'Cognitive and institutional predictors of initial trust toward an online retailer', International Journal of Retail \& Distribution Management, Vol. 39, No. 4, pp.234-255.

Éthier, J., Hadaya, P., Talbot, J. and Cadieux, J. (2008) 'Interface design and emotions experienced on B2C web sites: empirical testing of a research model', Computers in Human Behavior, Vol. 24, pp.2771-2791.

Ford, G. and Kotz, P. (2005) 'Designing usable interfaces with cultural dimensions', Proceedings of the 2005 IFIP TC13 international Conference on Human-Computer Interaction, SpringerVerlag, Rome, Italy, pp.713-726.

Ganguly, B., Dash, S.B. and Cyr, D. (2009) 'Website characteristics, trust and purchase intention in online stores: an empirical study in the Indian context', Journal of Information Science and Technology, Vol. 6, No. 2, pp.23-44. 
Ganguly, B., Dash, S.B. and Cyr, D. (2010) 'The effects of website design on purchase intentionin online shopping: the mediating role of trustand the moderating role of culture', Int. J. Electronic Business, Vol. 8, Nos. 4-5, pp.302-329.

Gefen, D. and Straub, D.W. (2004) 'Consumer trust in B2C e-Commerce and the importance of social presence: experiments in e-Products and e-Services', Omega, Vol. 32, No. 6, pp.407-424.

Gefen, D., Karahanna, E. and Straub, D.W. (2003) 'Trust and TAM in online shopping: an integrated model', MIS Quarterly, Vol. 27, No. 1, pp.51-90.

Grabner-Kräuter, S. (2009) 'Web 2.0 social networks: the role of trust', Journal of Business Ethics, Vol. 90, No. 4, pp.505-522.

Hansen, T. (2005) 'Perspectives on consumer decision making: an integrated approach', Journal of Consumer Behaviour, Vol. 4, No. 6, pp.420-437.

Hasan, L. and Abuelrub, E. (2011) 'Assessing the quality of web sites', Applied Computing and Informatics, Vol. 9, No. 1, pp.11-29.

Hasslinger, A., Hodzic, S. and Opazo, C. (2007) Online Consumer Behavior in Online Shopping, Kristianstad University.

Hofstede, G. (1980) Culture's Consequences: International Differences in Work-Related Values, Sage, Beverly Hills, CA.

Hofstede, G., Hofstede, G.J. and Minkov, M. (2010) Cultures and Organizations: Software of the Mind, Intercultural Cooperation and Its Importance for Survival, McGraw-Hill, USA.

Huynh, P.T. and Andrade, A.D. (2012) 'Effects of Web 2.0 experience on consumers' online purchase intention: the social networking and interaction orientation factors', International Conference on Information Resources Management, AIS, Vietnam, pp.1-16.

Hwang, Y. and Lee, K.C. (2012) 'Investigating the moderating role of uncertainty avoidance cultural values on multidimensional online trust', Information \& Management, Vol. 49, Nos. 3-4, pp.171-176.

Hyun-Hwa, L., Jihyun, K. and Ann, F. (2010) 'Affective and cognitive online shopping experience', Clothing \& Textiles Research Journal, Vol. 28, No. 2, pp.140-154.

Johnson, D. and Grayson, K. (2005) 'Cognitive and affective trust in service relationships', Journal of Business Research, Vol. 58, No. 4, pp.500-507.

Karimov, F.P., Brengman, M. and Hove, L.V. (2011) 'The effect of website design dimensions on initial trust: a synthesis of the empirical literature', Journal of Electronic Commerce Research, Vol. 12, No. 4, pp.272-301.

Kim, D.J. (2005) 'Cognition-based versus affect-based trust determinants in e-commerce: a cross-cultural comparison study', Twenty-Sixth International Conference on Information Systems (ICIS), AIS, Las Vegas, pp.741-753.

Kim, D.J. (2008) 'Antecedents of consumer trust in B2C electronic commerce and mobile commerce', Computer-Mediated Relationships and Trust: Managerial and Organizational Effects, IGI Global. Linda L. Brennan and Victoria E. Johnson, pp.158-176.

Kim, D.J., Ferrin, D.L. and Rao, H.R. (2008) 'A trust-based consumer decision-making model in electronic commerce: the role of trust, perceived risk, and their antecedents', Decis. Support Syst., Vol. 44, No. 2, pp.544-564.

Kim, J. and Forsythe, S. (2007) 'Hedonic usage of product virtualization technologies in online apparel shopping', International Journal of Retail \& Distribution Management, Vol. 35, No. 6, pp.502-514.

Kim, J. and Forsythe, S. (2009) 'Adoption of sensory enabling technology for online apparel shopping', European Journal of Marketing, Vol. 43, Nos. 9-10, pp.1101-1120.

Kim, S. and Park, H. (2013) 'Effects of various characteristics of social commerce (s-commerce) on consumers' trust and trust performance', International Journal of Information Management, Vol. 33, pp.318-332. 
Lawrence, J.E. and Usman, A. (2010) 'Barriers to ecommerce in developing countries', Information, Society and Justice, Vol. 3, No. 1, pp.23-35.

Lee, H.W., Osman, M.A., Zakaria, N. and Tan, B. (2010) 'Adoption of e-commerce online shopping in Malaysia', 2010 IEEE 7th International Conference on e-Business Engineering (ICEBE), Shanghai, pp.140-143.

Lee, J.A., Garbarino, E. and Lerman, D. (2007) 'How cultural differences in uncertainty avoidance affect product perceptions', International Marketing Review, Vol. 24, No. 3, pp.330-349.

Lee, M.K.O., Shi, N., Cheung, C.M.K., Lim, K.H. and Sia, C.L. (2011) 'Consumer's decision to shop online: the moderating role of positive informational social influence', Information \& Management, Vol. 48, No. 6, pp.185-191.

Lee, Y. and Kozar, K.A. (2010) 'Designing usable online stores: a landscape preference perspective', Information \& Management, pp.1-11.

Li, H., Sarathy, R. and Xu, H. (2011) 'The role of affect and cognition on online consumers' decision to disclose personal information to unfamiliar online vendors', Decision Support Systems, Vol. 51, No. 3, pp.434-445.

Lim, K., Leung, K., Sia, C.L. and Lee, M.K. (2004) 'Is ecommerce boundary-less? Effects of individualism-collectivism and uncertainty avoidance on internet shopping', Journal of International Business Studies, Vol. 35, No. 6, pp.545-559.

Lim, K.H., Sia, C.L., Lee, M.K.O. and Benbasat, I. (2006) 'Do I trust you online, and if so, Will I buy? An empirical study of two trust-building strategies', Journal of Management Information Systems, Vol. 23, No. 2, pp.233-266.

Lorenzo-Romero, C., Constantinides, E. and Alarcón-del-Amo, M-d-C. (2013) 'Web aesthetics effects on user decisions: impact of exposure length on website quality perceptions and buying intentions', Journal of Internet Commerce, Vol. 12, No. 1, pp.76-105.

McCoy, S., Galletta, D.F. and King, W.R. (2005) 'Integrating national culture into IS research: the need for current individual level measures', Communications of the Association for Information Systems, Vol. 15, pp.211-223.

McKnight, D.H. and Chervany, N.L. (2001) 'What trust means in e-commerce customer relationships: an interdisciplinary conceptual typology', Int. J. Electron. Commerce, Vol. 6, No. 2, pp.35-59.

McKnight, D.H., Choudhury, V. and Kacmar, C. (2002) 'The impact of initial consumer trust on intentions to transact with a web site: a trust building model', Journal of Strategic Information Systems, Vol. 11, pp.297-323.

McKnight, D.H., Cummings, L.L. and Chervany, N.L. (1998) 'Initial trust formation in new organizational relationships', Academy of Management Review, Vol. 23, No. 3, pp.473-490.

Mehrabian, A. and Russell, J.A. (1974) An Approach to Environmental Psychology, MIT, Cambridge, MA.

Najjar, L.J. (2011) 'Advances in e-commerce user interface design', Proceedings of the 1st International Conference on Human Interface and the Management of Information: Interacting with Information - Volume Part II, Springer-Verlag, Orlando, FL, pp.292-300.

Nielson (2012) How Digital Influences How We Shop Around the World, Company, T.N. (Ed.), Nielsen Global Survey.

Ou, C.X. and Sia, C.L. (2009) 'To trust or to distrust, that is the question: investigating the trustdistrust paradox', Commun. ACM, Vol. 52, No. 5, pp.135-139.

Palvia, P. (2009) 'The role of trust in e-commerce relational exchange: a unified model', Information \& Management, Vol. 46, No. 4, pp.213-220.

Pelet, J-É. (2011) 'The effect of e-commerce websites' colors on customer trust', International Journal of E-Business Research, Vol. 7, No. 3, pp.1-18.

Ringle, C.M., Wende, S. and Becker, J.M. (2014) 'Smartpls 3', SmartPLS, Hamburg [Online], Available: http://www.smartpls.com 
Roggio, A. (2008) The Importance of Web Accessibility for Ecommerce, Retrieved September, 2012, from http://www.getelastic.com/the-importance-of-web-accessibility-for-ecommerce/

Sambhanthan, A. and Good, A. (2012) 'Implications for improving accessibility to e-commerce websites in developing countries: a study of hotel websites', International Journal of Knowledge-Based Organizations, Vol. 2, No. 2, pp.1-20.

Sia, C.L., Lim, K.H., Leung, K., Lee, M.K.O. and Huang, W.W. (2009) 'Web strategies to promote internet shopping: Is cultural customization needed?', MIS Quarterly, Vol. 33, No. 3, pp.491-512.

Singh, N., Kumar, V. and Baack, D. (2005) 'Adaptation of cultural content: evidence from B2C e-commerce firms', European Journal of Marketing, Vol. 39, Nos. 1-2, pp.71-86.

Sinkovics, R.R., Yamin, M. and Hossinger, M. (2007) 'Cultural adaptation in cross border e-commerce: a study of German companies', Journal of Electronic Commerce Research, Vol. 8, No. 4, pp.221-235.

Smallman, W. (2006) Should E-Commerce Websites Support Web Accessibility by Law?, Retrieved September 2012, from http://www.blahblahtech.com/2006/11/should-e-commerce-websitessupport-web-accessibility-by-law.html

Sohaib, O. and Kang, K (2012) 'The role of technology, human and social networks in serviceable cross-cultural B2C websites', 19th International Business Information Management Conference (IBIMA), Barcelona, Italy, IBIMA.

Sohaib, O. and Kang, K. (2013) 'Importance of web accessibility in business-to-consumer (B2C) websites', 22nd Australasian Software Engineering Conference (ASWEC 2013), Doctoral Symposium, Retrieved March, 2014, from http://aswec2013.ict.swin.edu.au/ASWEC2013$\mathrm{PhD}$-Symposium/papers/paper_2.pdf

Sohaib, O. and Kang. K (2014) 'Cultural aspects of business-to-consumer (B2C) e-commerce: a comparative analysis of Pakistan and Australia', The Electronic Journal of Information Systems in Developing Countries, Vol. 61, pp.1-18.

Srite, M. and Karahanna, E. (2006) 'The role of espoused national cultural values in technology acceptance', MIS Quarterly, Vol. 30, No. 3, pp.679-704.

Sun, H. (2010) 'Sellers' trust and continued use of online marketplaces', Journal of the Association for Information Systems, Vol. 11, No. 4, pp.182-201.

Sun, H. (2011) 'Designing for social commerce experience as cultural consumption', Proceedings of the 4th international Conference on Internationalization, Design and Global Development, Springer-Verlag, Orlando, FL, pp.402-406.

Tan, F.B. and Sutherland, P. (2004) 'Online consumer trust: a multi-dimensional model', Journal of Electronic Commerce in Organizations (JECO), Vol. 2, No. 3, pp.40-58.

Te'eni, D. (2001) 'A cognitive-affective model of organizational communication for designing IT', MIS Quarterly, Vol. 25, No. 2, pp.251-312.

Teo, T.S.H. and Liu, J. (2007) 'Consumer trust in e-commerce in the United States, Singapore and China', Omega, Vol. 35, No. 1, pp.22-38.

Thabet, M. and Zghal, M. (2013) 'An exploratory approach to the influence of perceived social presence on consumer trust in a website', Journal of Internet and e-Business Studies, pp.1-20.

Thomas, P., Michaela, K. and Ralph, B. (2012) 'Integrating e-commerce and social engineering perspectives on trust in online communication', User-Centered Trust in Interactive SystemsNordiCHI 2012, ACM.

W3C (2005) Introduction to Web Accessibility, Retrieved 18 May, 2012, from http://www.w3.org/ WAI/intro/accessibility.php

Wang, Q. (2011) 'Usability research of interaction design for e-commerce website', 2011 International Conference on E-Business and E-Government (ICEE), pp.1-4.

WDI (2011) World Development Indicators, Internet Users.

Yoon, C. (2009) 'The effects of national culture values on consumer acceptance of e-commerce: online shoppers in China', Inf. Manage., Vol. 46, No. 5, pp.294-301. 
Appendix A: Questionnaire items

\begin{tabular}{|c|c|c|}
\hline \multicolumn{3}{|r|}{ Measures } \\
\hline Web accessibility & WA1 & The structure of this website is easy to understand \\
\hline \multirow{5}{*}{$\begin{array}{l}\text { Gefen et al. (2003), } \\
\text { Chen and Barnes } \\
\text { (2007), Yoon (2009), } \\
\text { Chen and Dibb (2010) } \\
\text { and Casaló et al. } \\
\text { (2011) }\end{array}$} & WA2 & Learning to operate this website is easy \\
\hline & WA3 & $\begin{array}{l}\text { When I am navigating this website, I feel that I am in control } \\
\text { of what I can do }\end{array}$ \\
\hline & WA4 & This website responds quickly \\
\hline & WA5 & This website helps me correct the errors I made \\
\hline & WA6 & My interaction with the website is understandable \\
\hline Colour & COL1 & The colours used in the website are emotionally appealing \\
\hline \multirow{2}{*}{$\begin{array}{l}\text { Chen and Dibb (2010) } \\
\text { and Cyr et al. (2010) }\end{array}$} & COL2 & The colour use on this website is attractive overall \\
\hline & COL3 & The brightness of pages on this website is adequate \\
\hline Images & IMG1 & This website has eye-catching images on the home page \\
\hline \multirow{2}{*}{$\begin{array}{l}\text { Kim and Forsythe } \\
\text { (2007), Chen and } \\
\text { Dibb (2010) and Cyr } \\
\text { (2013) }\end{array}$} & IMG2 & $\begin{array}{l}\text { Zooming and 3D images is helpful in buying what I want } \\
\text { through this website }\end{array}$ \\
\hline & IMG3 & $\begin{array}{l}\text { Overall, the screen design (i.e. colours, images, layout etc.) is } \\
\text { attractive }\end{array}$ \\
\hline $\begin{array}{l}\text { Social networking } \\
\text { services }\end{array}$ & SNS1 & This website clearly shows how I can contact the company \\
\hline \multirow{3}{*}{$\begin{array}{l}\text { McKnight et al. } \\
(2002) \text {, Hasslinger } \\
\text { et al. (2007) and } \\
\text { Huynh and Andrade } \\
\text { (2012) }\end{array}$} & SNS2 & $\begin{array}{l}\text { I believe using social networks services } \\
\text { (YouTube/Facebook/twitter/Google+) would help me in } \\
\text { decision making to purchase online }\end{array}$ \\
\hline & SNS3 & $\begin{array}{l}\text { I believe using the other support services (such as, FAQs, } \\
\text { ranking, online help, and contact details) would help me to buy } \\
\text { product I really want }\end{array}$ \\
\hline & SNS4 & $\begin{array}{l}\text { Reviews and rating of goods in this website would help me to } \\
\text { make a better decision to purchase online }\end{array}$ \\
\hline Cognitive-based trust & CTrust1 & I feel comfortable using this website to achieve my goals \\
\hline \multirow{3}{*}{$\begin{array}{l}\text { Lee and Kozar } \\
\text { (2010), Eastlick and } \\
\text { Lotz (2011), and } \\
\text { Brengman and } \\
\text { Karimov (2012) }\end{array}$} & CTrust2 & Promises made by this website are likely to be reliable \\
\hline & CTrust3 & I feel that I would be able to trust this website completely \\
\hline & CTrust 4 & $\begin{array}{l}\text { I believe that this retailer website knows how to provide } \\
\text { excellent services }\end{array}$ \\
\hline \multirow{3}{*}{$\begin{array}{l}\text { Affect-based trust } \\
\text { Kim (2008) and Lee } \\
\text { and Kozar (2010) }\end{array}$} & ATrust1 & $\begin{array}{l}\text { I expect that this retailer website is ready and willing to assist } \\
\text { and support me }\end{array}$ \\
\hline & ATrust2 & Visiting this retailer website is enjoyable \\
\hline & ATrust3 & This retailer website is trustworthy \\
\hline \multirow{3}{*}{$\begin{array}{l}\text { Purchase intention } \\
\text { Chen and Barnes } \\
\text { (2007), Yoon (2009) } \\
\text { and Kim and Park } \\
\text { (2013) }\end{array}$} & PINT1 & I am likely to purchase the product(s) from this retailer website \\
\hline & PINT2 & $\begin{array}{l}\text { Given the opportunity, I intend to place a purchase from this } \\
\text { retailer website }\end{array}$ \\
\hline & PINT3 & $\begin{array}{l}\text { It is likely that I will actually purchase products from this } \\
\text { retailer website in the near future }\end{array}$ \\
\hline
\end{tabular}




\section{Appendix A: Questionnaire items (continued)}

\begin{tabular}{|c|c|c|}
\hline \multicolumn{3}{|r|}{ Measures } \\
\hline $\begin{array}{l}\text { Uncertainty } \\
\text { avoidance }\end{array}$ & UA1 & $\begin{array}{l}\text { I prefer to avoid making changes while online shopping } \\
\text { because things could get worse }\end{array}$ \\
\hline \multirow{2}{*}{$\begin{array}{l}\text { Srite and Karahanna } \\
\text { (2006), Yoon (2009) } \\
\text { and Hwang and Lee } \\
(2012)\end{array}$} & UA2 & $\begin{array}{l}\text { Rules and regulations of the online stores are important to me } \\
\text { because they inform buyers what the online store does }\end{array}$ \\
\hline & UA3 & $\begin{array}{l}\text { Standard operating procedures of an online store are helpful to } \\
\text { me for the purchase decisions }\end{array}$ \\
\hline \multirow{3}{*}{$\begin{array}{l}\text { Individualism } \\
\text { Srite and Karahanna } \\
\text { (2006) and Yoon } \\
(2009)\end{array}$} & IDV1 & $\begin{array}{l}\text { Group success is more important than individual success in } \\
\text { online shopping }\end{array}$ \\
\hline & IDV2 & $\begin{array}{l}\text { Having autonomy is more important than being accepted as a } \\
\text { member of a group }\end{array}$ \\
\hline & IDV3 & Individual's rewards are more important than group benefits \\
\hline
\end{tabular}

\section{Appendix B: Multigroup PLS analysis}

Multi-group PLS analysis is a component-based SEM that allows the comparisons of structural model differences across cultural groups (Chin, 2004). It is performed by taking the standard errors for the structural model paths and comparing the equivalent paths across different groups (Pakistan and Australia in this study) by performing t-tests on their path coefficients.

$$
t=\frac{\text { Path }_{\text {sample_1 }}-\text { Path }_{\text {sample_2 }}}{\sqrt{\frac{(m-1)^{2}}{(m+n-2)} \times S . E_{\text {sample1 }}^{2}+\frac{(n-1)^{2}}{(m+n-2)} \times S . E_{\text {sample2 }}^{2} \times\left[\sqrt{\frac{1}{m}+\frac{1}{n}}\right]}}
$$

where

$\begin{array}{ll}\text { S.E.: } & \text { Standard error } \\ \text { Path }_{\text {sample }}: & \text { Path coefficients in each structural model } \\ m, n: & \text { Sample sizes of dataset } \\ (m+n-2): & \text { Degree of freedom. }\end{array}$

